Bul. Agrohorti 3 (1) : 127 - 136 (2015)

\title{
Pemanfaatan Residu Biomulsa Arachis pintoi dan Legum Lainnya pada Pola Tanam Rotasi Jagung- Tomat
}

\author{
The Usage of Arachis pintoi and Other Legume Biomulches Residue in Corn-Tomato Cropping System
}

\author{
Fathurrahman Aziz Munawir dan M.A Chozin*
}

\author{
Departemen Agronomi dan Hortikultura, Fakultas Pertanian, Institut Pertanian Bogor \\ (Bogor Agricultural University), Jl Meranti, Kampus IPB Darmaga, Bogor 16680, Indonesia \\ Telp \& Faks 62-251-8629353 e-mail: agronipb@indo.net.id \\ *Penulis untuk korespondensi : ma_chozin@yahoo.com
}

Disetujui 7 Januari 2015 / Published Online 15 Januari 2015

\begin{abstract}
The purpose of this study was to compare the influence of Arachis pintoi biomulch residue with residue of other biomulches on tomato cultivation in corn-tomato cropping system. This experiment was held at the Cikabayan Experimental Field, Dramaga Bogor in November 2014 until April 2015. This experiment was conducted in randomized complete block design (RCBD) with one factor, which is the residue of biomulches type with 6 rate of treatments and 3 replication in the Permata F1 tomato plant. The results showed that the residue of biomulches type can increase the soil nutrient status, size of the diameter of the tomatoes stem, yield components, tomato production, and shifting the types of weeds. The residue Arachis pintoi biomulch can increase soil nutrient status and tomato production that were better than the residue of other legumes biomulch.
\end{abstract}

Keywords: Arachis pintoi, biomulch residue, production, weeds

\begin{abstract}
ABSTRAK
Tujuan dari penelitian ini adalah untuk membandingkan pengaruh residu biomulsa Arachis pintoi dengan residu biomulsa lainnya pada budidaya tanaman tomat dengan pola tanam rotasi jagung-tomat. Percobaan ini dilaksanakan di Kebun Percobaan Cikabayan, Dramaga, Bogor pada bulan November 2014 sampai April 2015. Percobaan ini menggunakan rancangan kelompok lengkap teracak (RKLT) satu faktor yaitu residu jenis biomulsa dengan 6 taraf perlakuan dan 3 ulangan pada tanaman tomat varietas Permata F1. Hasil penelitian menunjukkan bahwa residu biomulsa meningkatkan status hara tanah, diameter batang, komponen hasil, produksi tomat, dan mempengaruhi pergeseran jenis gulma. Secara umum residu biomulsa Arachis pintoi dapat meningkatkan status hara tanah dan produksi tomat yang cenderung lebih baik daripada residu biomulsa legum lainnya.
\end{abstract}

Kata kunci: Arachis pintoi, gulma, produksi, residu biomulsa 


\section{PENDAHULUAN}

Penurunan kualitas sumberdaya lingkungan pada masa kini mengakibatkan terancamnya lahan pertanian di masa depan. Oleh karena itu pertanian pada masa kini mulai berfokus terhadap budidaya tanaman yang ramah lingkungan. Salah satu upaya yang dapat dilakukan adalah dengan menerapkan sistem pola tanam rotasi diiringi pemakaian input bahan organik. Disamping itu, kendala yang kerap dijumpai dalam pertanian organik adalah jumlah input bahan organik yang digunakan sangat besar. Perlu dilakukan kajian tentang efisiensi jenis bahan organik yang digunakan agar dapat diperoleh produksi yang berkelanjutan. Pendekatan yang dapat dilakukan adalah melalui pemanfaatan residu tumbuhan pada lahan dengan sistem pola tanam rotasi.

Pemanfaatan residu dari sisa tanaman yang tumbuh maupun vegetasi yang ada pada lahan pertanaman terbukti sangat baik untuk peningkatan status hara tanah. Yakup (2002) menjelaskan bahwa biomulsa pada budidaya tanaman dapat digunakan sebagai pupuk hijau. Berbagai penelitian telah dilakukan dengan memanfaatkan bahan sisa yang mampu mengurangi kandungan $\mathrm{Al}$ dapat ditukar di dalam tanah (Wahjudin, 2006), dan dalam bentuk pupuk hijau kering dari tumbuhan legum Gliricidia sepium yang mampu meningkatkan hasil pipilan kering jagung (Wawan et al, 2007). Contoh biomulsa legum yang umum digunakan residunya yaitu Calopogonium mucunoides, Centrosema pubescens, dan Arachis pintoi.

Chozin et al (2014) mengemukakan bahwa biomulsa Arachis pintoi memiliki berbagai kelebihan, khususnya untuk penanaman tomat. Kelebihan Arachis pintoi meliputi hal-hal berikut, yaitu tinggi tanaman yang rendah, pertumbuhan merata, serta memiliki persentase penutupan tanah yang tinggi. Proses pembenaman diperlukan agar residu tanaman dapat terdekomposisi, sehingga unsur hara yang terkandung dapat diserap oleh tanaman dan menambahkan bahan-bahan organik ke dalam tanah (Rahim, 2006). Residu tersebut diharapkan dapat meningkatkan kesuburan tanah dan dapat mempengaruhi hasil produksi monokultur tanaman tomat.

Pola tanam jagung yang diberi biomulsa sesuai untuk dirotasikan ke tanaman sayuran buah seperti tomat, karena tanaman dapat terhindar dari hama dan penyakit (McGrath, 2009). Es (2009) menjelaskan bahwa rotasi tanaman juga dapat membantu pembentukan bahan organik tanah dari akar tumbuhan yang telah mati selama masa bera. Efek lain yang perlu diperhatikan yaitu pertumbuhan gulma berupa suksesi setelah pengolahan lahan. Setelah pengolahan tanah, pergeseran jenis tersebut juga diperkirakan akan menumbuhkan jenis-jenis gulma baru yang akan tumbuh di saat monokultur tomat. Mahfudz (2005) mengatakan bahwa dinamika infestasi gulma pada suatu lahan sangat ditentukan oleh biji gulma yang merupakan alat perkembangbiakannya. Biji dari jenis gulma yang terdapat di dalam tanah serta dormansi biji gulma selama penanaman jagung dapat mempengaruhi suksesi gulma. Suksesi gulma tersebut juga akan mempengaruhi pertumbuhan dan produksi tanaman tomat. Penelitian ini bertujuan untuk membandingkan pengaruh residu biomulsa Arachis pintoi dengan residu biomulsa legum lainnya terhadap status hara tanah, pergeseran jenis gulma, pertumbuhan dan produksi tanaman tomat pada pola tanam rotasi jagung-tomat.

\section{BAHAN DAN METODE}

Percobaan dilaksanakan pada bulan November 2014 hingga April 2015 di kebun percobaan Cikabayan-University Farm IPB Dramaga Bogor. Lokasi penelitian memiliki topografi datar dengan ketinggian $250 \mathrm{~m}$ di atas permukaan laut.

Bahan yang digunakan terdiri dari benih tomat varietas Permata F1, lahan bekas penanaman jagung dengan perlakuan berbagai mulsa yang telah diberakan selama 16 bulan yaitu vegetasi gulma, Arachis pintoi, Centrosema pubescens, Calopogonium mucunoides, dan Mulsa Plastik Hitam Perak (MPHP). Pupuk yang digunakan adalah pupuk kandang dengan dosis 20 ton ha ${ }^{-1}$, pupuk NPK mutiara, pupuk daun Gandasil-D, dan pupuk daun Gandasil-B. Bahan lainnya yaitu arang sekam, bambu, carbofuran, dan fungisida. Alat yang digunakan terdiri dari peralatan tanam, tray penyemaian, meteran, jangka sorong, alat tulis, timbangan digital, oven, kertas oven, gelas ukur, dan kuadran $50 \mathrm{~cm}$ x $50 \mathrm{~cm}$.

Percobaan ini merupakan penelitian lanjutan yang menggunakan Rancangan Kelompok Lengkap Teracak (RKLT) faktor tunggal dengan 3 ulangan, yaitu penanaman tomat pada lahan yang sebelumnya ditanami jagung dengan perlakuan berbagai residu jenis biomulsa yang terdiri dari: vegetasi tanpa mulsa yang tidak disiangi (B0), vegetasi tanpa mulsa dengan penyiangan (B1), vegetasi yang diberi MPHP (B2), Arachis pintoi 
(B3), Centrosema pubescens (B4), dan Calapogonium mucunoides (B5). Model matematika yang digunakan mengacu pada model Gomez dan Gomez (1995).

Lahan yang digunakan untuk penelitian adalah lahan bekas penanaman jagung dengan perlakuan berbagai biomulsa yang telah diberakan sekitar enam belas bulan. Pengolahan tanah dilakukan sebulan sebelum penanaman tanaman tomat dengan pembenaman seluruh biomulsa beserta vegetasi lainnya. Petakan dibuat menggunakan cangkul dengan ukuran $5 \mathrm{~m}$ x $4 \mathrm{~m}$, jarak antar petak $30 \mathrm{~cm}$, jarak antar ulangan $50 \mathrm{~cm}$, dan kedalaman $20 \mathrm{~cm}$. Pemberian pupuk kandang dilakukan dengan memasukkan pupuk di tiap lubang tanam secara merata setelah bedengan dibuat, kemudian dibiarkan selama dua minggu. Benih tomat disemai terlebih dahulu di tray persemaian dengan media tanam berupa campuran tanah, pupuk kandang, dan arang sekam dengan perbandingan 1 : 1: 1. Setelah itu tray diletakkan pada tempat yang tidak terkena sinar matahari langsung dan air hujan. Setiap hari penyiraman dilakukan pada pagi dan sore hari. Setelah lima minggu, bibit tomat ditanam ke lahan pada waktu sore hari. Jarak lubang tanam tomat yang digunakan adalah $50 \mathrm{~cm} \times 60 \mathrm{~cm}$. Lubang tanam kemudian diberi carbofuran sebelum bibit ditanam.

Pemeliharaan tanaman tomat yang dilakukan meliputi penyulaman, pengajiran, penyiangan gulma, pemupukan, dan pengendalian hama penyakit. Penyulaman mulai dilakukan pada satu minggu setelah tanam (MST). Pengajiran dengan bambu dilakukan pada 2 MST. Penyiangan gulma secara manual dilakukan pada seminggu sebelum penanaman tomat, 4 MST, dan 8 MST disesuaikan dengan waktu analisis vegetasi gulma. Pengendalian hama dilakukan secara manual dengan pemindahan dan pemusnahan hama, sedangkan pengendalian penyakit bercak daun dilakukan dengan penyemprotan fungisida dithane.

Pemupukan dimulai setelah tomat ditanam di lapang. Berdasarkan rekomendasi dari Baharuddin (2010), tomat pada awal pertumbuhan diberikan Gandasil-D dengan konsentrasi $2 \mathrm{~g} / \mathrm{l}$ dan dengan volume semprot sebesar 51 untuk tiap ulangan. Selama fase vegetatif (2 MST - 7 MST) pemupukan tomat menggunakan NPK mutiara dengan konsentrasi $10 \mathrm{~g} / 1$ dan dengan volume sebesar 101 untuk tiap ulangan seminggu sekali. Setelah tomat masuk ke fase generatif (8 MST - 11 MST) diberi pupuk daun Gandasil-B dengan konsentrasi 2 g/l dan dengan volume semprot sebesar 51 untuk tiap ulangan. Pemanenan tomat dilakukan saat tanaman telah berumur 70 - 90 hari setelah tanam. Pemanenan dilakukan secara bertahap dengan cara memetik buah pada tahap light red sampai buah habis. Hasil panen dikelompokkan berdasarkan tiap satuan percobaan.

Untuk mengetahui status hara tanah, dilakukan analisis tanah pada sebelum dan sesudah percobaan. Pengambilan contoh tanah dilakukan secara komposit dengan pengambilan tanah sedalam $\pm 20 \mathrm{~cm}$. Analisis meliputi $\mathrm{pH}$, kandungan Corganik, N-total, nisbah $\mathrm{C} / \mathrm{N}, \mathrm{P}_{2} \mathrm{O}_{5}$ Bray, Morgan $\mathrm{K}_{2} \mathrm{O}$, dan nilai tukar kation $(\mathrm{Ca}, \mathrm{Mg}, \mathrm{K}$, dan $\mathrm{Na}$ ) di Laboratorium Tanah Balai Penelitian Tanah Cimanggu Bogor.

Parameter yang diamati pada percobaan ini terdiri dari pertumbuhan tomat, hasil dan produksi tomat, kualitas buah tomat, serta pertumbuhan dan pergeseran jenis gulma. Tanaman contoh yang diamati masing-masing 10 tanaman tomat yang dipilih secara acak setiap satuan percobaan. Pertumbuhan vegetatif yang diamati terdiri dari diameter batang $(\mathrm{mm})$, tinggi tanaman $(\mathrm{cm})$, dan jumlah daun (helai) yang dilakukan setiap minggu sejak 2-7 MST. Pertumbuhan generatif yang diamati terdiri dari jumlah bunga per tanaman dan jumlah bunga menjadi buah per tanaman. Perhitungan jumlah bunga dilakukan saat $75 \%$ dari populasi telah berbunga hingga $10 \mathrm{MST}$. Hasil dan produksi tomat yang diamati terdiri dari bobot buah per tanaman $(\mathrm{g})$, diameter buah per tanaman $(\mathrm{cm})$, jumlah buah per tanaman, produksi per tanaman $(\mathrm{g})$, dan produksi berdasarkan luas ubinan $2.4 \mathrm{~m}$ x $2.5 \mathrm{~m}$ per satuan percobaan (g) yang dilakukan setelah panen.

Pertumbuhan dan pergeseran jenis gulma saat sebelum dan setelah rotasi jagung-tomat ditentukan oleh dominasi gulma yang dihitung melalui analisis vegetasi gulma. Analisis vegetasi gulma terdiri dari pengamatan jenis gulma, jumlah gulma, bobot kering gulma, dan dominasi gulma. Dilaksanakan pada saat seminggu sebelum pengolahan lahan dan saat 30 dan 60 HST tomat di lapang dengan cara pengambilan dua titik acak per petak satuan percobaan menggunakan kuadran $50 \mathrm{~cm}$ x $50 \mathrm{~cm}$.

Dominasi gulma dihitung menggunakan rumus berikut ini : 


$$
\mathrm{NJD}=\frac{K N+F N+B K N}{3}
$$

Keterangan $:$ NJD = Nisbah jumlah dominasi, $\mathrm{KN}=$ Kerapatan nisbi, FN = Frekuensi nisbi, BKN = Bobot kering nisbi

Data yang diperoleh dari percobaan dianalisis menggunakan perangkat lunak SAS 9.1.3 Portable, melalui sidik ragam (uji F) agar dapat diketahui pengaruh perlakuan residu biomulsa setelah rotasi tanaman jagung ke tanaman tomat. Apabila menunjukkan pengaruh nyata dilakukan uji lanjut Duncan's Multiple Range Test (DMRT) pada taraf $5 \%$.

\section{HASIL DAN PEMBAHASAN}

\section{Kondisi Umum}

Menurut data iklim bulan November 2014 hingga April 2015 dari Badan Meteorologi Klimatologi dan Geofisika (BMKG) Dramaga, lokasi percobaan memiliki rata-rata suhu udara sebesar $26^{\circ} \mathrm{C}$, rata-rata kelembaban sebesar $84.71 \%$, dan rata-rata curah hujan sebesar $323 \mathrm{~mm}$ bulan $^{-1}$. Ashari (2006) dan Cahyono (2008) mengemukakan bahwa suhu optimal untuk tomat berkisar antara 20$25{ }^{\circ} \mathrm{C}$ serta curah hujan optimal untuk tomat yaitu 100-200 mm bulan ${ }^{-1}$. Hama dan penyakit pada tanaman tomat mulai muncul sejak 2 MST seiring dengan kondisi lahan yang lembab dan curah hujan yang tinggi. Serangan hama yang terlihat pada fase vegetatif yaitu patahnya pangkal batang tomat yang diduga disebabkan oleh hama ulat tanah (Agrotis ipsilon), daun yang dimakan oleh ulat grayak (Spodoptera litiura) dan belalang (Oxya chinensis), sedangkan pada saat fase generatif yaitu ulat penggerek buah (Helicoverpa armigera).

Penyakit yang menyerang pada fase vegetatif yaitu layu bakteri, bercak daun yang diduga oleh cendawan Alternaria solani, puru akar oleh nematoda genus Meloidogyne, dan serangan virus famili Geminiviridae dengan genus Begomovirus yaitu TYLCV (Tomato Yellow Leaf Curl Virus) dengan gejala tanaman kerdil serta daun kuning mengkerut. Pengendalian untuk tanaman yang terkena TYLCV yaitu dengan pembuangan dan pemusnahan di tempat yang jauh dari lokasi percobaan. Gangguan hama dan penyakit tersebut serupa dengan percobaan penanaman tomat dengan biomulsa Arachis pintoi oleh Chozin et al (2014) dan Febrianto (2012), sehingga biomulsa Arachis pintoi maupun residunya masih belum efektif untuk pengendalian hama dan penyakit. Persentase kematian tanaman tomat akibat serangan hama dan penyakit tersebut berkisar hingga $28 \%$ dari keseluruhan populasi, sehingga penyulaman tanaman dilakukan hingga 2 MST. Gangguan dari gulma juga mempengaruhi pertumbuhan dan produksi tomat. Gulma yang mendominasi memperoleh kesempatan yang lebih besar dalam perebutan air dan hara di dalam tanah yang ditujukan untuk tanaman tomat. Dampak yang disebabkan oleh gangguan hama, penyakit, dan gulma terhadap potensi hasil cukup besar karena menurunkan kualitas buah dan menghilangkan jumlah hasil produksi.

\section{Peningkatan Status Hara Tanah}

Lahan yang digunakan merupakan lahan bekas percobaan budidaya jagung yang menggunakan perlakuan berbagai jenis biomulsa dan vegetasi lainnya. Analisis tanah yang dilakukan pada percobaan sebelumnya menunjukkan bahwa biomulsa Arachis pintoi dapat meningkatkan status hara tanah yang lebih baik daripada biomulsa lainnya (Silmi dan Chozin, 2014). Setelah lahan dibera 16 bulan, analisis tanah dilakukan kembali sebanyak dua tahap waktu yaitu saat sebelum dan setelah perlakuan residu jenis biomulsa.

Kondisi tanah sebelum perlakuan residu biomulsa menunjukkan bahwa tanah bersifat masam dan memiliki kadar bahan organik serta kapasitas tukar kation (KTK) yang rendah. Penyebab rendahnya kandungan hara tersebut diduga karena pencucian hara oleh air hujan dan penyerapan hara oleh gulma-gulma dominan selama sebelum perlakuan. Hasil analisis pada akhir perlakuan menunjukkan bahwa terjadi peningkatan status hara tanah dari setiap perlakuan (Tabel 1). Bahkan setelah percobaan selesai masih terdapat jumlah unsur-unsur hara tersedia bagi tanaman yang lebih tinggi daripada saat sebelum perlakuan. Kondisi tanah menjadi lebih subur setelah menerima residu dari biomulsa. Tanah dikatakan subur apabila nisbah $\mathrm{C} / \mathrm{N}$ berkisar antara 1 sampai 11 (Sutanto, 2002).

Kualitas pH, C-organik, N-total, $\mathrm{P}_{2} \mathrm{O}_{4}$, kation $\mathrm{Ca}$, kation $\mathrm{Mg}$, dan kejenuhan basa yang terbaik diantara perlakuan lainnya terdapat pada perlakuan B3. Status hara tanah pada perlakuan B3 di akhir perlakuan berturut-turut yaitu C-organik sebesar $1.67 \%$, N-total sebesar $0.19 \%, \mathrm{~K}_{2} \mathrm{O}$ sebesar $65 \mathrm{ppm}$, kation Ca sebesar $6.46 \mathrm{cmol} \mathrm{g}^{-1}$, kation $\mathrm{Mg}$ sebesar $1.24 \mathrm{cmol} \mathrm{g}^{-1}$, kation $\mathrm{K}$ sebesar $0.13 \mathrm{cmol} \mathrm{g}^{-1}$, kation 
Na sebesar $0.26 \mathrm{cmol} \mathrm{g}^{-1}$, KTK sebesar $12.3 \mathrm{cmol} \mathrm{g}$ ${ }^{1}$, dan kejenuhan basa sebesar $66 \%$. Kualitas rasio $\mathrm{C} / \mathrm{N}$, kation $\mathrm{Na}$, dan KTK yang terbaik terdapat pada perlakuan B4, sedangkan untuk kualitas terbaik dalam paremeter kandungan $\mathrm{K}_{2} \mathrm{O}$ dan kation K terdapat pada perlakuan B1 (Tabel 1).

Tabel 1. Status hara tanah pada awal perlakuan dan akhir perlakuan residu jenis biomulsa

\begin{tabular}{|c|c|c|c|c|c|c|c|c|c|c|c|c|c|}
\hline \multirow{2}{*}{ No } & \multirow{2}{*}{ Parameter } & \multicolumn{7}{|c|}{-----------------Sebelum perlakuan-------------- } & \multicolumn{5}{|c|}{ 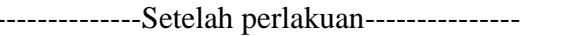 } \\
\hline & & B0 & B1 & B2 & B3 & B4 & B5 & B0 & B1 & B2 & B3 & B4 & B5 \\
\hline 1. & $\mathrm{pH}$ & 5 & 5.2 & 5 & 4.8 & 5 & 4.8 & 5.1 & 4.9 & 4.9 & 5.1 & 4.9 & 4.9 \\
\hline 2. & C-Organik & 1.97 & 1.46 & 1.5 & 1.37 & 1.57 & 1.54 & 1.33 & 1.45 & 1.42 & 1.67 & 1.54 & 1.48 \\
\hline 3. & N-Total (\%) & 0.16 & 0.16 & 0.18 & 0.18 & 0.19 & 0.15 & 0.14 & 0.17 & 0.13 & 0.19 & 0.19 & 0.17 \\
\hline 4. & $\mathrm{C} / \mathrm{N}$ & 12 & 9 & 8 & 8 & 8 & 10 & 10 & 9 & 11 & 9 & 8 & 9 \\
\hline 5. & $\mathrm{P}_{2} \mathrm{O}_{5}$ Bray $(\mathrm{ppm})$ & 31.5 & 5.5 & 12 & 17.3 & 13.5 & 9.6 & 17.4 & 11.8 & 11.1 & 12.3 & 11.9 & 12.4 \\
\hline 6. & $\begin{array}{l}\text { Morgan } \mathrm{K}_{2} \mathrm{O} \\
\text { (ppm) }\end{array}$ & 102 & 38 & 42 & 52 & 38 & 67 & 85 & 148 & 61 & 65 & 33 & 31 \\
\hline 7. & $\mathrm{Ca}\left(\mathrm{cmol} \mathrm{g}^{-1}\right)$ & 4.24 & 3.76 & 4.95 & 4.81 & 4.85 & 4.23 & 3.56 & 3.27 & 4.45 & 6.46 & 5.26 & 5.93 \\
\hline 8. & $\operatorname{Mg}\left(\mathrm{cmol} \mathrm{g}^{-1}\right)$ & 0.03 & 0.79 & 0.67 & 0.86 & 0.7 & 0.64 & 0.86 & 0.84 & 0.66 & 1.24 & 0.81 & 0.61 \\
\hline 9. & $\mathrm{~K}\left(\mathrm{cmol} \mathrm{g}^{-1}\right)$ & 0.2 & 0.07 & 0.08 & 0.19 & 0.13 & 0.13 & 0.06 & 0.06 & 0.12 & 0.12 & 0.27 & 0.05 \\
\hline 10. & $\mathrm{Na}\left(\mathrm{cmol} \mathrm{g}^{-1}\right)$ & 0.3 & 0.08 & 0.19 & 0.13 & 0.13 & 0.13 & 0.06 & 0.06 & 0.12 & 0.26 & 0.27 & 0.05 \\
\hline 11. & KTK $\left(\mathrm{cmol} \mathrm{g}^{-1}\right)$ & 11.74 & 11.41 & 12.16 & 11.44 & 13.25 & 11.89 & 11.65 & 10.67 & 11.62 & 12.3 & 14.24 & 11.62 \\
\hline 12. & $\mathrm{~KB}^{*}(\%)$ & 41 & 41 & 48 & 52 & 43 & 43 & 40 & 42 & 46 & 66 & 45 & 57 \\
\hline
\end{tabular}

Keterangan: $\mathrm{B} 0=$ residu vegetasi tanpa mulsa yang tidak disiangi, B1= residu vegetasi tanpa mulsa dengan penyiangan, B2= residu dari vegetasi yang diberi MPHP, B3= residu Arachis pintoi, B4= residu Centrosema pubescens, dan B5= residu Calapogonium mucunoides; $*>100$ : terdapat kation-kation bebas disamping kation dapat ditukar; Sumber: Laboratorium Tanah Balai Penelitian Tanah Cimanggu Bogor (2015).

Berdasarkan hasil analisis tanah, tanah dengan residu Arachis pintoi cenderung memiliki status hara tanah yang lebih baik dari perlakuan lainnya. Hal ini diduga karena kelebihan biomulsa Arachis pintoi yang tergolong kedalam tumbuhan legum dan sifat residunya yang lebih lunak daripada biomulsa lainnya. Proses dekomposisinya dapat berjalan lebih cepat dan penurunan kandungan nitrat terjadi dalam periode yang relatif singkat daripada tumbuhan non-legum (Sutanto, 2002), serta lebih banyak menambah bahan organik ke dalam tanah, memperbaharui sifat fisik tanah, dan memperkaya nutrien dalam tanah (Johnson dan Toensmeier, 2009). Kecepatan proses dekomposisi juga dipengaruhi oleh faktor cuaca (suhu, kelembaban) dan jenis serta organ tumbuhan yang diaplikasikan (Wijaya, 2008). Suhu, curah hujan, dan kelembaban yang tinggi di lokasi menyebabkan seluruh residu vegetasi dari tiap perlakuan mudah membusuk, sehingga waktu untuk proses dekomposisi menjadi semakin lebih cepat.

\section{Pergeseran Jenis Gulma}

Hasil analisis vegetasi gulma yang dilakukan pada saat sebelum perlakuan, 30 HST, dan 60 HST terdiri dari gulma yang tergolong ke dalam 8 famili dan 27 spesies. Secara umum, sebelum perlakuan (setelah diberakan selama 16 bulan) seluruh petak percobaan didominasi oleh gulma golongan rumput. Setelah perlakuan residu biomulsa dibenamkan, terjadi pergeseran jenis gulma namun tidak terdapat perbedaan jenis gulma yang tumbuh pada 30 dan 60 HST. Jenis gulma yang tumbuh pada seluruh petak percobaan secara umum menjadi didominasi oleh golongan daun lebar, tetapi jenis gulma rumput Imperata cylindrica masih mampu bertahan dengan nilai NJD yang tinggi (Tabel 2).

Jenis gulma yang paling dominan dari golongan daun lebar adalah Mitracarpus villosus, gulma sukulen berstolon yang baru muncul dan terdapat di seluruh perlakuan. Hal ini menunjukkan bahwa jenis gulma Mitracarpus villosus merupakan gulma yang mampu bersaing pada pola tanam rotasi jagung-tomat. Gulma baru lainnya yang tumbuh adalah teki (Cyperus rotundus) dengan nilai NJD yang rendah dan hanya terdapat pada perlakuan B0 (4\%), B2 (1.92\%), dan B5 (1.74\%).

Petakan dengan residu biomulsa Arachis pintoi mampu menekan pertumbuhan gulma rumput Imperata cylindrica yang lebih baik daripada residu biomulsa legum lainnya, namun tidak mampu menekan gulma daun lebar Mitracarpus villosus sebaik petakan dengan residu biomulsa Centrosema pubescens. Seluruh 
perlakuan menunjukkan bahwa pada saat $60 \mathrm{HST}$ sudah tidak ditemukan lagi keberadaan jenis gulma Pennisetum polystachyon, Panicum maxima, Paspalum comersonii, Centrosema pubescens, dan Arachis pintoi. Hal ini diduga rotasi dan pembenaman seluruh vegetasi ke dalam tanah pada petakan masing-masing tersebut dapat memutus siklus hidup dari jenis-jenis gulma tersebut. Perlakuan residu dari biomulsa legum menunjukkan adanya perbedaan pengaruh dari jenis legum yang dibenamkan. Petakan dengan residu Arachis pintoi menunjukkan keragaman jenis gulma yang paling sedikit daripada residu biomulsa legum lainnya, yaitu pada petakan dengan residu Arachis pintoi sebanyak 3 jenis gulma rumput dan 5 jenis gulma daun lebar, pada petakan dengan residu Centrosema pubescens sebanyak 2 jenis gulma rumput dan 7 jenis gulma daun lebar, sedangkan pada petakan dengan residu Calapogonium mucunoides sebanyak 5 jenis gulma rumput, 4 jenis gulma daun lebar, dan 1 jenis gulma teki (Tabel 2).

Tabel 2. NJD dari golongan gulma rumput, daun lebar, dan teki pada setiap perlakuan saat sebelum perlakuan dan 60 HST

\begin{tabular}{|c|c|c|c|c|c|c|c|c|c|c|c|c|c|}
\hline \multirow{3}{*}{ No. } & \multirow{3}{*}{$\begin{array}{l}\text { Golongan dan jenis } \\
\text { Gulma }\end{array}$} & \multicolumn{12}{|c|}{ Nisbah Jumlah Dominasi (\%) } \\
\hline & & \multicolumn{6}{|c|}{--------------Sebelum perlakuan-------------- } & \multicolumn{6}{|c|}{ 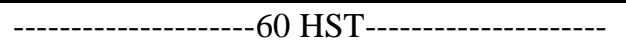 } \\
\hline & & $\mathrm{B} 0$ & B1 & $\mathrm{B} 2$ & B3 & B4 & B5 & B0 & B1 & B2 & B3 & B4 & B5 \\
\hline & Rumput & & & & & & & & & & & & \\
\hline 1. & Imperata cylindrica & 13.3 & - & 23.86 & 32.99 & 17.8 & 25.93 & 32.76 & 48.76 & 44.1 & 31.25 & 58.3 & 36.77 \\
\hline 2. & $\begin{array}{l}\text { Pennisetum } \\
\text { polystachyon }\end{array}$ & 19.33 & 13.12 & 11.88 & 8.78 & 13.89 & 10.18 & - & - & - & - & - & - \\
\hline 3. & Panicum maxima & 11.76 & - & 14.52 & - & 18.84 & 9.04 & - & - & - & - & - & - \\
\hline 4. & Rotboelia exaltata & - & - & - & 3.57 & 3.75 & 7.8 & 2.68 & - & 4.39 & 3.93 & - & 4.2 \\
\hline 5. & $\begin{array}{l}\text { Paspalum } \\
\text { comersonii }\end{array}$ & - & 18.45 & 6.35 & 13.27 & 5.03 & 1.9 & - & - & - & - & - & - \\
\hline 6. & $\begin{array}{l}\text { Lain-lain ( } 8 \text { spesies) } \\
\text { Daun lebar }\end{array}$ & 22.36 & 35.73 & 13.37 & 16.78 & - & - & 14.25 & 15.07 & 8.18 & 7.03 & 5.67 & 11.67 \\
\hline 1. & $\begin{array}{l}\text { Calapogonium } \\
\text { mucunoides }\end{array}$ & 17.26 & 6.92 & 5.37 & 5.16 & 7.94 & 11.4 & 10.8 & - & 10.27 & 9.67 & - & 2.33 \\
\hline 2. & Borreria alata & 1.67 & 6.76 & 6.23 & - & 4.05 & 5.57 & 6.8 & 6.86 & 6.77 & - & 2.81 & 10.14 \\
\hline 3. & Asystasia intrusa & 8.89 & 6.38 & 8.25 & - & 9.02 & 8.92 & 2.87 & - & - & - & 3.99 & - \\
\hline 4. & Mimosa invisa & - & 6.11 & 4.5 & 1.95 & 2.98 & - & 3.7 & - & 6.5 & - & 2.81 & - \\
\hline 5. & $\begin{array}{l}\text { Mitracarpus } \\
\text { villosus }\end{array}$ & - & - & - & - & - & - & 10.1 & 19.96 & 10.27 & 20.41 & 8.41 & 30.63 \\
\hline 6. & Centrosema pubescens & - & - & 5.67 & - & 16.7 & 19.26 & - & - & - & - & - & - \\
\hline 7. & Arachis pintoi & - & - & - & 15.5 & - & - & - & - & - & - & - & - \\
\hline 8. & $\begin{array}{l}\text { Lain-lain (7 spesies) } \\
\text { Teki }\end{array}$ & 5.43 & 6.53 & - & 2 & - & - & 12.04 & 9.35 & 7.6 & 27.71 & 18.01 & 2.52 \\
\hline 1. & Cyperus rotundus & - & - & - & - & - & - & 4 & - & 1.92 & - & - & 1.74 \\
\hline
\end{tabular}

Keterangan: $\mathrm{B} 0=$ residu vegetasi tanpa mulsa yang tidak disiangi. B1= residu vegetasi tanpa mulsa dengan penyiangan. B2 = residu dari vegetasi yang diberi MPHP. B3= residu Arachis pintoi. B4= residu Centrosema pubescens. dan B5= residu Calapogonium mucunoides.

Petakan dengan residu biomulsa Arachis pintoi mampu menekan kemunculan jenis gulma Pennisetum polystachyon, Panicum maxima, Paspalum comersonii, Borreria alata, Asystasia intrusa, dan Mimosa invisa. Selain itu residu biomulsa Arachis pintoi juga mampu menekan pertumbuhan gulma dominan dari golongan rumput yang lebih baik daripada residu biomulsa legum lainnya yaitu Imperata cylindrica, namun tidak mampu menekan gulma daun lebar Mitracarpus villosus sebaik petakan dengan residu biomulsa Centrosema pubescens.
Hal ini diduga karena perbedaan residu jenis biomulsa yang dibenamkan menimbulkan efek senyawa alelopati yang berbeda, sehingga dapat mempengaruhi pertumbuhan vegetasi yang akan tumbuh kemudian (Junaedi et al , 2006). Pergeseran jenis gulma yang tumbuh di lahan juga dipengaruhi oleh persaingan antar spesies dalam kemampuan penyerapan cahaya, kemampuan penyerapan air, kemampuan penyerapan hara (Martin dan Sauerborn, 2013), kemampuan alat perkembangbiakan untuk perbanyakan jenisnya (Widiyanto, 2012), dan lama waktu dormansi yang dialami (Syarifi, 2010). 


\section{Pertumbuhan dan Produksi Tomat}

Secara umum perlakuan residu biomulsa berpengaruh nyata terhadap parameter diameter batang, bobot per buah, diameter buah, produksi per tanaman, dan produksi ubinan. Rekapitulasi sidik ragam pengaruh perlakuan perbedaan jenis residu biomulsa terhadap pertumbuhan dan produksi tomat disajikan dalam Tabel 3.

Tabel 3. Rekapitulasi sidik ragam pengaruh perlakuan perbedaan jenis residu biomulsa terhadap pertumbuhan dan produksi tomat

\begin{tabular}{|c|c|c|}
\hline Parameter & F hitung & $\mathrm{KK}(\%)$ \\
\hline Diameter batang (mm) & $* *$ & 3.53 \\
\hline Tinggi tanaman $(\mathrm{cm})$ & tn & 8.01 \\
\hline Jumlah daun (helai) & $\operatorname{tn}$ & 2.14 \\
\hline Jumlah bunga & tn & 4.70 \\
\hline Jumlah bunga menjadi buah & tn & 5.22 \\
\hline Bobot per buah $(\mathrm{g})$ & $* *$ & 6.05 \\
\hline Jumlah buah & tn & 4.66 \\
\hline Diameter buah $(\mathrm{cm})$ & $* *$ & 1.03 \\
\hline Produksi per tanaman (g) & $* *$ & 6.97 \\
\hline Produksi ubinan (g) & $* *$ & 8.11 \\
\hline
\end{tabular}

Keterangan : ${ }^{* *}=$ berbeda nyata pada taraf $1 \% ; *$ berbeda nyata pada taraf $5 \%$; th $=$ tidak berbeda nyata; KK $=$ Koefisien keragaman

\section{Pertumbuhan Tanaman Tomat}

Perlakuan jenis residu biomulsa memberikan pengaruh yang nyata terhadap pertumbuhan vegetatif kecuali parameter tinggi tanaman, jumlah daun, dan pertumbuhan generatif tomat (Tabel 3). Perlakuan B0 memiliki ukuran rata-rata diameter yang paling besar $(5.41 \mathrm{~mm})$ berbeda nyata dengan B2 $(4.80 \mathrm{~mm})$. B4 (5.12 $\mathrm{mm})$. dan B5 (4.45 mm). Rata-rata diameter batang tanaman tomat pada perlakuan B3 (5.40 $\mathrm{mm}$ ) lebih besar dan berbeda nyata dibandingkan dengan rata-rata diameter tomat pada perlakuan B4 $(5.12 \mathrm{~mm})$. perlakuan B5 $(4.45 \mathrm{~mm})$. dan perlakuan B2 (4.80 mm). Selanjutnya pada Tabel 4 rata-rata tinggi tanaman tomat dari tiap perlakuan adalah $74.38 \mathrm{~cm}$ dan tidak berbeda nyata dengan perlakuan lainnya.

Tabel 4. Pertumbuhan vegetatif dan generatif tomat pada berbagai perlakuan residu jenis biomulsa

\begin{tabular}{|c|c|c|c|c|c|}
\hline \multirow[b]{2}{*}{ Perlakuan } & \multirow{2}{*}{$\begin{array}{c}\text { Diameter } \\
\text { batang }(\mathrm{mm})\end{array}$} & \multicolumn{2}{|c|}{ Vegetatif $\quad$-------------------- } & \multicolumn{2}{|c|}{--------- Generatif - -------- } \\
\hline & & $\begin{array}{l}\text { Tinggi tanaman } \\
(\mathrm{cm})\end{array}$ & $\begin{array}{l}\text { Jumlah daun } \\
\text { (helai) }\end{array}$ & Jumlah bunga & $\begin{array}{l}\text { Jumlah bunga } \\
\text { menjadi buah }\end{array}$ \\
\hline B0 & $5.41 \mathrm{a}$ & 75.55 & 13.97 & 21.67 & 16.10 \\
\hline B1 & $5.26 \mathrm{a}$ & 76.65 & 14.13 & 21.43 & 15.30 \\
\hline B2 & $4.80 \mathrm{~b}$ & 75.68 & 13.77 & 21.00 & 15.50 \\
\hline B3 & $5.40 \mathrm{a}$ & 80.50 & 13.87 & 21.53 & 16.13 \\
\hline B4 & $5.12 \mathrm{ab}$ & 69.66 & 13.93 & 21.83 & 15.47 \\
\hline B5 & $4.45 \mathrm{c}$ & 65.23 & 13.63 & 21.83 & 16.03 \\
\hline
\end{tabular}

Keterangan: $\mathrm{B} 0=$ residu vegetasi tanpa mulsa yang tidak disiangi. $\mathrm{B} 1=$ residu vegetasi tanpa mulsa dengan penyiangan. $\mathrm{B} 2=$ residu dari vegetasi yang diberi MPHP. B3= residu Arachis pintoi. B4= residu Centrosema pubescens. dan B5= residu Calapogonium mucunoides; angka yang diikuti huruf yang sama pada kolom yang sama tidak berbeda nyata menurut uji DMRT 5

Residu dari biomulsa Arachis pintoi (B3) dapat meningkatkan ukuran diameter batang yang cenderung lebih baik dari perlakuan lainnya.
Seperti yang dikemukakan oleh Chozin et al (2014). bahwa pemanfaatan Arachis pintoi sebagai biomulsa dapat meningkatkan komponen 
pertumbuhan tomat seperti tinggi tanaman. jumlah daun. jumlah ruas. dan panjang ruas. Hal ini menjelaskan bahwa Arachis pintoi yang dimanfaatkan residunya maupun digunakan sebagai biomulsa sangat baik untuk meningkatkan komponen pertumbuhan tomat. Arachis pintoi juga termasuk ke dalam tumbuhan legum. dimana sifat residu tumbuhan legum memiliki kemampuan khusus untuk memberikan unsur $\mathrm{N}$ yang lebih banyak ke dalam tanah (Sutanto, 2002).

Tanaman tomat mulai berbunga pada umur pada umur 5 MST. namun sebagian besar tanaman (75\% dari jumlah populasi) tomat berbunga pada umur 8 MST. Tabel 4 menyajikan nilai rata-rata jumlah bunga dan jumlah bunga berbuah yang diamati pada 10 MST. yaitu saat tanaman sudah berhenti berbunga. Rata-rata jumlah bunga yang muncul berkisar antara 21-22 bunga dan bunga yang menjadi buah berkisar antara 15-16 bunga dari tiap perlakuan. Rata-rata persentase bunga yang menjadi buah cukup rendah. yaitu sebesar $73.15 \%$.

Komponen Hasil dan Produksi Tanaman Tomat
Rekapitulasi sidik ragam pada Tabel 3 menunjukkan bahwa perlakuan residu biomulsa memberikan pengaruh nyata terhadap seluruh parameter komponen hasil dan produksi tomat kecuali parameter jumlah buah. Secara keseluruhan nilai peubah tertinggi terdapat pada perlakuan B0 dan terkecil pada perlakuan B5 (Tabel 5). Rata-rata bobot per buah pada perlakuan B3 (Arachis pintoi) adalah 25.75 g. lebih tinggi dan berbeda nyata dengan rata-rata bobot buah pada perlakuan biomulsa lainnya (B1. B2. B4. dan B5) yang berturut-turut sebesar 22.49 g. 23.17 g. 20.80 g. dan 20.31 g. Selanjutnya pada Tabel 5 dapat dilihat bahwa rata-rata diameter buah pada perlakuan B3 adalah $3.43 \mathrm{~cm}$. Nilai ini berbeda nyata dan lebih tinggi dari perlakuan lainnya tetapi lebih kecil dari perlakuan B0 yang memiliki ukuran rata-rata sebesar $3.53 \mathrm{~cm}$. Secara umum nilai rata-rata bobot per buah berbanding lurus dengan rata-rata diameter buah, namun diameter buah rata-rata pada perlakuan B5 tidak berbeda nyata dengan perlakuan B4 dan B1. Perlakuan residu Arachis pintoi (B3) juga menghasilkan jumlah buah rata-rata per tanaman terbanyak (21.03 buah). tetapi tidak berbeda nyata dengan perlakuan residu biomulsa lainnya.

Tabel 5. Produksi tomat pada berbagai perlakuan residu jenis biomulsa

\begin{tabular}{ccccccc}
\hline Perlakuan & $\begin{array}{c}\text { Bobot per } \\
\text { buah }(\mathrm{g})\end{array}$ & $\begin{array}{c}\text { Diameter } \\
\text { buah }(\mathrm{cm})\end{array}$ & $\begin{array}{c}\text { Jumlah } \\
\text { buah }\end{array}$ & $\begin{array}{c}\text { Produksi per } \\
\text { tanaman }(\mathrm{g})\end{array}$ & $\begin{array}{c}\text { Produksi ubinan } \\
2.4 \mathrm{~m} \mathrm{x} \mathrm{2.5} \mathrm{m}(\mathrm{g})\end{array}$ & $\begin{array}{c}\text { Produksi per } \\
\text { hektar (ton) }\end{array}$ \\
\hline B0 & $27.90 \mathrm{a}$ & $3.53 \mathrm{a}$ & 20.77 & $560.57 \mathrm{a}$ & $7147 \mathrm{a}$ & 4.46 \\
B1 & $22.49 \mathrm{bc}$ & $3.15 \mathrm{~d}$ & 20.30 & $442.93 \mathrm{~cd}$ & $5493 \mathrm{~cd}$ & 3.27 \\
B2 & $23.17 \mathrm{~b}$ & $3.24 \mathrm{c}$ & 20.43 & $486.20 \mathrm{bc}$ & $6137 \mathrm{bc}$ & 3.99 \\
B3 & $25.75 \mathrm{a}$ & $3.43 \mathrm{~b}$ & 21.03 & $533.60 \mathrm{ab}$ & $6693 \mathrm{ab}$ & 4.10 \\
B4 & $20.80 \mathrm{bc}$ & $3.13 \mathrm{~d}$ & 19.00 & $386.47 \mathrm{~d}$ & $5017 \mathrm{de}$ & 3.26 \\
B5 & $20.31 \mathrm{c}$ & $3.09 \mathrm{~d}$ & 19.63 & $382.00 \mathrm{~d}$ & $4587 \mathrm{e}$ & 3.35 \\
\hline
\end{tabular}

Keterangan: $\mathrm{B} 0=$ residu vegetasi tanpa mulsa yang tidak disiangi. $\mathrm{B} 1=$ residu vegetasi tanpa mulsa dengan penyiangan. $\mathrm{B} 2=\mathrm{residu}$ dari vegetasi yang diberi MPHP. B3= residu Arachis pintoi. B4= residu Centrosema pubescens. dan B5= residu Calapogonium mucunoides; angka yang diikuti huruf yang sama pada kolom yang sama tidak berbeda nyata menurut uji DMRT $5 \%$.

Produksi rata-rata per tanaman tertinggi dihasilkan oleh perlakuan B0 dan berbeda nyata dengan perlakuan lainnya. namun hanya memiliki selisih $26.97 \mathrm{~g}$ dengan hasil produksi rata-rata per tanaman pada perlakuan B3 (Tabel 5). Hal ini menunjukkan bahwa produksi per tanaman pada perlakuan residu Arachis pintoi (B3) tidak berbeda dengan perlakuan residu vegetasi tanpa mulsa yang tidak disiangi (B0). Secara khusus dibandingkan dengan residu jenis biomulsa legum lainnya. produksi rata-rata per tanaman dari perlakuan B3 adalah $147.13 \mathrm{~g}$ lebih tinggi dari perlakuan B4 dan
151.6 g lebih tinggi dari perlakuan B5. Rata-rata produksi tomat jika dilihat dalam luasan ubinan 2.4 $\mathrm{m} \times 2.5 \mathrm{~m}$ pada perlakuan B0 juga memiliki nilai tertinggi dan berbeda nyata dengan perlakuan lainnya. Merujuk pada Tabel 5. dapat dilihat bahwa perlakuan residu Arachis pintoi (B3) menghasilkan produksi ubinan sebesar $6693 \mathrm{~g}$. Nilai tersebut juga lebih tinggi dan berbeda nyata dengan perlakuan residu biomulsa legum lainnya (Centrosema pubescens dan Calapogonium mucunoides). yang secara berturut-turut memiliki selisih $1676 \mathrm{~g}$ dan $2106 \mathrm{~g}$. 
Berdasarkan hasil secara keseluruhan, perlakuan yang memiliki pengaruh terbaik terhadap pengingkatan hasil produksi tomat adalah perlakuan residu vegetasi tanpa mulsa yang tidak disiangi atau vegetasi alami (B0). Hal ini disebabkan oleh keragaman jenis vegetasinya yang tinggi serta di dalam residu dari vegetasinya juga terdapat tumbuhan legum yang terindentifikasi melalui analisis vegetasi gulma (Tabel 2), yaitu Calapogonium mucunoides sehingga kombinasi tersebut cenderung mampu menghasilkan $\mathrm{P}$ yang lebih tinggi dari perlakuan lainnya (Tabel 1). Unsur P dibutuhkan oleh tomat untuk pertumbuhan dan perkembangan hingga saat waktu pembentukan buah dan khususnya dibutuhkan untuk proses transfer energi pada jaringan tanaman (Jones, 2008).

Keunggulan jenis biomassa Arachis pintoi yang lebih lunak dari biomulsa legum lainnya menyebabkan karbohidrat dan protein dari jaringannya lebih mudah terdekomposisi menjadi fosfat, sulfat, nitrat, amoniak, karbon dioksida, air dan beberapa unsur lain seperti kalsium. Berlimpahnya humus yang terbentuk memudahkankan tanaman untuk menyerap air dan hara dalam kapasitas yang tinggi dari dalam tanah (Sutanto, 2002). Selain itu. manfaatnya juga telah terbukti lebih baik dalam peningkatan produksi tomat daripada perlakuan residu biomulsa legum lainnya. Hal ini mengindikasikan bahwa pemanfaatan residu dari biomulsa Arachis pintoi lebih baik daripada biomulsa legum lainnya.

\section{KESIMPULAN DAN SARAN}

\section{Kesimpulan}

Residu dari berbagai jenis biomulsa dapat meningkatkan status hara tanah dan produksi tomat serta mempengaruhi pergeseran jenis gulma. Peningkatan status hara tanah, komponen hasil dan produksi tomat pada perlakuan residu Arachis pintoi lebih tinggi daripada perlakuan residu biomulsa legum Centrosema pubescens dan Calapogonium mucunoides. Petakan dengan residu Arachis pintoi mampu menekan kemunculan gulma Pennisetum polystachyon, Panicum maxima, Paspalum comersonii, Borreria alata, Asystasia intrusa dan Mimosa invisa.

\section{DAFTAR PUSTAKA}

Ashari, S. 2006. Hortikultura Aspek Budidaya. Revisi ke-1. Jakarta (ID): UI Press.

Cahyono, B. 2008. Tomat: Usaha Tani \& Penanganan Pascapanen. Revisi ke-5. Yogyakarta (ID): Kanisius.

Chozin, M.A., Kartika, J.G., dan Baharuddin, R. 2010. Penggunaan kacang hias (Arachis pintoi) sebagai biomulsa pada budidaya tomat (Lycopercicon esculentum). J Hort Indonesia. 4(3):168-174.

Es, H.V. 2009. Crop Rotation and Soil Tilth. Chapter 3: Physical and Biological Processes in Crop Rtation. Crop Rotation on Organic Farms: A Planning Manual. Mohler CL dan Johnson SE. editor. New York (US): NRAES.

Febrianto, Y. 2012. Pengaruh Jarak Tanam dan Jenis Stek terhadap Kecepatan Penutupan Arachis pintoi Krap. \& Greg. Sebagai Biomulsa pada Pertanaman Tomat (Licopersicon esculentum M.) [Skripsi]. Bogor (ID): Institut Pertanian Bogor.

Gomez, K.A., dan Gomez, A.A. 1995. Prosedur Statistika untuk Penelitian Pertanian. Terjemahan dari: Stathistical Procedure for Agricultural Research. Sjamsudin E dan Bahasjah JS. penerjemah. Jakarta (ID): UI Pr.

Johnson, S.E., dan Toensmeier, E. 2009. How Expert Organic Farmers Manage Crop Rotations. Crop Rotation on Organic Farms: A Planning Manual. Mohler CL dan Johnson SE. editor. New York (US): NRAES.

Jones, J.B.Jr. 2008. Tomato Plant Culture: In the Field. Greenhouse. and Home Garden. Ed ke-2. Boca Raton (US): CRC Pr

Junaedi, A., Chozin, M.A., dan Kwang, Ho.K. 2006. Ulasan: Perkembangan terkini kajian alelopati. Hayati. 13(2):79-84 
Mahfudz. 2005. Dinamika Infestasi dan Karakter Ekofisiologi Gulma di Daerah Penyangga Taman Nasional Lore Lindu [Disertasi]. Bogor (ID): Institut Pertanian Bogor.

Martin, K., dan Sauerborn, J. 2013. Agroecology. London (GB): Springer

McGrath, M.T. 2009. Managing Plant Diseases with Crop Rotation. Chapter 3: Physical and Biological Processes in Crop Rtation. Crop Rotation Organic Farms: A Planning Manual. Mohler CL dan Johnson SE. editor. New York (US): NRAES.

Melati, M. Asiah, A., dan Rianawati, D. 2008. Aplikasi pupuk organik dan residunya untuk produksi kedelai panen muda. Bul Agron. 36(3):204-213.

Rahim, S.E. 2006. Pengendalian Erosi Tanah Dalam Rangka Pelestarian Lingkungan Hidup. Jakarta (ID): Bumi Aksara.
Silmi, F., dan Chozin, M.A. 2014. Pemanfaatan biomulsa kacang hias (Arachis pintoi) pada budidaya jagung manis (Zea mays saccharata Sturt.) di lahan kering. J Hort Indonesia. 5(1):1-9.

Sutanto, R. 2002. Penerapan Pertanian Organik: Pemasyarakatan dan Pengembangannya. Yogyakarta (ID): Kanisius

Syarifi N. 2010. Pemanfaatan Mulsa Gulma untuk Pengendalian Gulma pada Tanaman Kedelai di Lahan Kering [Skripsi]. Bogor (ID): Institut Pertanian Bogor.

Wahjudin, U.M. 2006. Pengaruh pemberian kapur dan kompos sisa tanaman terhadap aluminium dapat ditukar dan produksi tanaman kedelai pada tanah vertic hapludult dari gajrug. banten. Bul Agron. 34(3):141-147. 